\title{
Martyna KOWALSKA
}

Uniwersytet Jagielloński

martyna.kowalska@o2.pl

\section{KULTUROWY I SPOŁECZNY \\ PORTRET STILIAGÓW'}

\author{
POMNIK NIEZNANEGO STILIAGI, DOROSE A CÓRKA \\ MŁODEGO CZŁOWIEKA WIKTORA SŁAWKINA
}

\begin{abstract}
A Cultural and Social Portrait of Stilyaga (V. Slavkin, The Monument to the Unknown Stilyaga, The Grown-up Daughter of the Young Man)

The article presents a cultural and social portrait of the first youth subculture in the Soviet Union. The inspiration for the study of the literary phenomenon of stilyaga were the works of Victor Slavkin: a drama The Grown-up Daughter of a Young Man and a memoir The Monument to the Unknown Stilyaga. A memoir of Alexey Kozlov and a work of Vasiliy Aksyonov In Search of Melancholy Baby complemented the study. The cultural portrait of stilyaga was based on works from the field of sociology and cultural studies, as well as drafts and articles on the official government stand towards the rebellious youth. The literary portrait of stilyaga is dominated by a romantic, nostalgic vision and a specific idealization of the young years. The image of the subculture, however remote from authenticity, was transferred to other arts: film, musical culture, photography. The article attempts to separate the myth of stilyaga from the facts.
\end{abstract}

Słowa kluczowe: stiliaga, prace V. Slavkina, nonkonformizm, rosyjska Nowa Fala, subkultury w ZSRR

Stiliagi (стиляги) - nazwa pierwszej radzieckiej subkultury młodzieżowej. Początek ruchu w większych miastach ZSRR wiąże się z latami bezpośrednio po Wielkiej Wojnie Ojczyźnianej. Mając na uwadze rosyjską specyfikę ruchu młodzieżowego, w tekście będziemy używać oryginalnej nazwy pisanej alfabetem łacińskim. 
Key-words: stilyaga, works of V. Slavkin, nonconformity, Russian New Wave plays, subcultures in the USSR

$\mathrm{F}$ enomen pierwszej radzieckiej subkultury młodzieżowej od dawna inspirował zarówno socjologów, badaczy kultury, jak i twórców literatury. W ostatnich latach ten powojenny ruch młodzieży został barwnie zekranizowany w filmie Walerija Todorowskiego Bikiniarze (Стимяги, 2008). Cieszący się ogromną popularnością obraz filmowy nie tylko przybliżył młodszej części widowni zapomnianą już subkulturę, ale też zaprezentował ją w oryginalny sposób, zmieniając dotychczasową refleksyjno-sentymentalną tonację na groteskowe widowisko z dużą dawką dobrej muzyki i tańca. Istotnie, Todorowski wyszedł poza ramy dominującego w kulturze kanonu opisu tej subkultury młodzieżowej, umiejętnie omijając problematykę nostalgii i rozważań o bezpowrotnie utraconej młodości. Osoby dotychczas poruszające temat stiliagów, zwłaszcza byli członkowie subkultury, koncentrowały się nie tylko na opisie samego zjawiska, ale również na sentymentalnych wspomnieniach z okresu młodzieńczego (Aleksiej Kozłow, Koziot na saksie, Козем на саксе, 1998) bądź zawierających promień nadziei latach odwilży i wierze w nieograniczone możliwości wstępującego pokolenia (Wasilij Aksionow, W poszukiwaniu smutnego baby, В поисках грустного беби, 1985).

W powyższy kanon obrazowania subkultury wpisuje się utwór Wiktora Sławkina Dorosta córka mtodego cztowieka (Взрослая дочь молодого человека, 1972). Sztuka zyskała ogromną popularność dzięki teatralnej adaptacji w reżyserii Anatolija Wasiliewa, której premiera odbyła się w 1979 r. na deskach Teatru im. Konstantina Stanisławskiego w Moskwie. Życzliwe przyjęcie spektaklu przez publiczność oraz uznanie w gronie krytyków zaowocowały kolejnym dramatem poświęconym stiliagom - Serso (Cepco, 1979), wystawionym przez Wasiliewa w 1985 r. Oba utwory należą do tzw. nowej fali dramaturgii radzieckiej i stanowią konfrontację marzeń byłych stiliagów z dojrzałym okresem ich życia, pełnym rozczarowań. W Serso pisarz zrezygnował z dynamicznej akcji oraz tradycyjnego konfliktu, wynikającego ze sprzecznych dążeń postaci, na rzecz konfliktu wewnętrznego ${ }^{2}$. O różnicach, a także więzi łączącej utwory Sławkin pisał: Dorosła córka - spojrzenie wstecz. Serso - spojrzenie do przodu. Z jednego punktu widzenia. A raczej z punktu widzenia ludzi będacych w jednym wieku ${ }^{3}$. Bohaterami dramatów są członkowie subkultury stiliagów, ukazani z blisko dwudziestoletniej perspektywy czasowej, która umożliwia konfrontację młodzieńczych ideałów i marzeń z rzeczywistością.

Wydawać by się mogło, że retrospektywne zagadnienie, poświęcone latom młodości, Sławkin wyczerpał wraz z drugą sztuką. Tymczasem na początku lat 90. dramaturg powrócił do stiliagów w prozatorskiej odsłonie. W książce Pomnik nieznanego sti-

Historia literatury rosyjskiej XX wieku, red. A. Drawicz, Warszawa 2002, s. 524-525.

3 В. Славкин, Памятник неизвестному стиляге, Москва 1996, s. 301. Wszystkie tłumaczenia tekstów obcojęzycznych, jeśli nie podano inaczej, moje - M.K. 
liagi (Памятник неизвестному стиляге, 1992) temat został wzbogacony o barwne wspomnienia oscylujące wokół inscenizacji Dorostej córki..., historie byłych członków subkultury, a także wycinki prasowe poświęcone zjawisku „westernizacji” młodzieży radzieckiej. Książka zawiera dwuaktowy utwór oraz cenne komentarze, poszerzone o monologowe wypowiedzi pierwszoplanowych bohaterów, stanowiące dopełnienie utworu. Pomnik... pełni funkcję podręcznika do właściwego odczytania sztuki. Jest również inspiracją do poznania historii subkultury oraz odautorską refleksją nad fenomenem stiliagów.

Utwór wpisuje się w nurt wspomnieniowy, którego tłem jest społeczno-obyczajowy wycinek radzieckiej rzeczywistości, obejmujący okres od wczesnych lat 50. do późnych lat $80 . \mathrm{XX}$ w. W warstwie strukturalnej stanowi mozaikę tematów, gatunków, rodzajów i stylów. Dominantą tematyczną jest historia powstania dramatu oraz teatralnej inscenizacji w reżyserii Wasiliewa. W niniejszy wątek wplecione są czasem zabawne, niekiedy tragiczne opowieści o losach osób związanych z radziecką dramaturgią i teatrem (aktorów, reżyserów, krytyków i cenzorów), czasopiśmiennictwem, literaturą. Sławkin przytacza szereg historii z życia kulturalnego radzieckiej stolicy, z poczuciem humoru kreśląc paradoksy egzystencji w Związku Radzieckim. Interesującą odsłoną kulisów powstania dramatu oraz wspomnień są trzy spotkania z alter ego postaci Bemsa - Sławą Nadieżdinem, jednym z pierwszych stiliagów w Moskwie. Całość dopełniają archiwalne noty prasowe, recenzje sztuki oraz anegdoty i zasłyszane historie z życia zwykłych obywateli ZSRR.

Wątkiem równoległym, ściśle związanym ze sztuką i historią jej powstania, jest efemeryczny ruch młodzieżowy, znany w Rosji Radzieckiej pod nazwą stiliagi. Autor nie tylko opisuje subkulturę, szczegółowo charakteryzując modę młodzieży, język, zainteresowania, muzykę, rodzaj więzi między jej członkami, ale zastanawia się również nad jej fenomenem, kreśląc historię walki władzy z pierwszym masowym przejawem indywidualizmu w granicach systemu. W luźne refleksje Sławkin włącza „dowody rzeczowe” - fragmenty książek, artykuły z gazet i listy do redakcji pisane przez „czujnych” członków społeczeństwa radzieckiego. W'śród autorów są nie tylko bezimienni komsomolcy, mieszkańcy małych miast i wsi, ale również uznani twórcy kultury i działacze partyjni (Maksym Gorki, Wsiewołod Koczetow, Anatolij Sofronow). Jednocześnie dramaturg prezentuje liczne opowieści z życia radzieckich stiliagów, ujawnia światopogląd wybranych członków ruchu, przytacza rosyjskie warianty światowych przebojów jazzowych, a także luźne monologi bohaterów dramatu Dorosta córka..., stanowiące uzupełnienie charakterologicznych rysów postaci.

Nie bez znaczenia jest także pozycja samego autora w odniesieniu do subkultury. Sławkin odgrywa rolę znawcy powojennego ruchu młodzieży, bystrego obserwatora, a jednocześnie bywalca wieczorków tanecznych w rytmie boogie woogie. $Z$ tego względu wstydliwe wyznanie Sławkina, ograniczające się do jednego zdania: Nigdy nie bytem stiliaga (Памятник..., s. 255), wprowadza duży element zaskoczenia i niedowierzanie. $\mathrm{Na}$ swoją obronę autor Serso przytacza kilka okoliczności, które uniemożliwiły mu zasilenie szeregów nonkonformistycznej stołecznej młodzieży: niski wzrost i wątła postura, nieśmiałość - zwłaszcza w kontaktach z płcią piękną oraz niezamożność jego rodziny: 
nasza rodzina żyta z jednej pensji ojca [...], nie mogtem sobie pozwolić na bycie stiliaga (Памятник..., s. 257). Sławkin przyznaje, że był zafascynowany kulturą stiliagów: literaturą (Ernest Hemingway, Erich Maria Remarque i in.), malarstwem (m.in. Pablo Picasso), kultowymi amerykańskimi filmami, muzyką jazzową, a także modą, tańcem i slangiem. Stiliagą jednak nigdy nie został. Szczera wypowiedź autora nasuwa myśl, że członkami tej subkultury mogli zostać nieliczni, którym pozwalały na to stan majątkowy i społeczna pozycja rodziców. Z tego względu stiliagą nie pozostawało się długo. Po kilku latach fascynacji kulturą amerykańską „złota młodzież” przechodziła na stonowane pozycje, by zająć intratną posadę w resortach ojców i ich dobrze sytuowanych znajomych.

Autor Pomnika... kreśli także dalsze losy pierwszoplanowej postaci dramatu, Bemsa (prototypem bohatera był Nadieżdin, kolega Sławkina ze studiów). Kolejne spotkania ze starzejącym się stiliagą ukazują, że fascynacja Zachodem nie minęła, oryginalność jest wciąż ważna w jego życiu prowadzonym pod prąd jednobarwnemu, nudnemu społeczeństwu. Zainteresowanie Nadieżdina kulturą zachodnią nasiliło się z chwilą otwarcia granic i pojawieniem się nowych możliwości poznania „zakazanego owocu”. Temat spotkania Sławkina z pierwszym stiliagą Moskiewskiego Instytutu Kolejnictwa jest jednym z kontekstów, w których można rozpatrywać tytuł memuaru. Pomnik nieznanego stiliagi jako pamięć o koledze ze studiów, którego losów dramaturg nie był w stanie przewidzieć. W sztuce Dorosta córka... alter ego Nadieżdina jawi się jako podstarzały, zgnuśniały inteligent, którego krąg życia ogranicza się do monotonnej, niskopłatnej pracy, kłopotów z dorastającą córką i kłótni z żoną. Bems nie lubi pogrążać się we wspomnieniach o swojej brawurowej młodości, co czyni go postacią tragiczną, niepotrafiącą pogodzić się z przemijającym życiem. Jest także inny wariant rozpatrywania tytułu książki, który nasuwa jej autor - pomnik jako hołd złożony wszystkim radzieckim stiliagom, pierwszym nonkonformistom w ZSRR, zachłyśniętym powiewem iluzorycznej wolności.

Klamrą spajającą dwa wyżej wymienione wątki wspomnień jest refleksja nad pokoleniem szestidiesiatników ${ }^{4} \mathrm{i}$ ich dalszymi losami. Sławkin, inspirowany artykułami prasowymi z końca lat 80., kontynuuje temat rosyjskich „przeklętych problemów”, stawiając pytanie o współczesne losy pokolenia nonkonformistów czasów odwilży. Szczególne zainteresowanie budzą w nim „bezimienni” tamtych lat, pozostający na obrzeżach kultury, polityki i społeczeństwa: Istniato kilka możliwości, by ocalić się wewnętrznie, duchowo, przestrzegać higieny socjalnej, nie ubrudzić się, przetrwać jako osoba itd. Oto najważniejsze: pierwsza - wyjechać, emigrować, uciec na zawsze; druga - zostać dysydentem, rewolucjonista-partyzantem, wojownikiem. Jednak jeśli cztowiek, mimo wszystko, nie wyjeżdza, a ponad to nie ma odpowiednego socjalnego ifizycznego charakteru, by zajmowaćsie walka - to co mu zostaje? Obrzeża. I wtaśnie tam odchodzit. Tam żyt. Niebogato, pospolicie, beznadziejnie, lecz w zamian pośród swoich książek, ze swoja muzyka, wieszając na ścianach reprodukcje ulubionych obrazów, zdjęcia swoich przyjaciót... (Памятник..., s. 215).

Zob. więcej: П. Вайль, А. Генис, 60-е. Мир советского чемовека, Ann Arbor 1988; „Przegląd Rusycystyczny" 2011, nr 2: Odwilż i pokolenie lat sześćdziesiątych. 
Sławkin również siebie wpisuje w grono szestidiesiatników, pozostających na obrzeżach, pogrążonych we wspomnieniach o minionej burzliwej młodości, co mocną kreską zarysował w sztuce Serso. Autor poruszył ważny temat, który w latach pierestrojki zyskał na znaczeniu: zagadnienie pokolenia szestidiesiatników jako pokolenia straconych szans, kolejne wcielenie zbędnych ludzi. Powyższy problem jest ściśle związany z konfliktem pokoleń oraz postrzeganiem szestidiesiatników przez ich następców, nazywanych „pokoleniem Pepsi”, generacją „P”. W latach 80. do głosu doszło kolejne pokolenie, „dzieci XX Zjazdu”, sprzeciwiające się ideałom „ojców” i ich metodom walki. Rozłam widoczny między dwoma pokoleniami Sławkin nakreślił już w dramacie Dorosta córka..., jednak w swoich wspomnieniach nadał temu problemowi autentyczny ton, nasycony głęboką refleksją nad rolą szestidiesiatników w historii Związku Radzieckiego i drogą jaką podążyli ich następcy - dzieci pierestrojki.

\section{SPOŁECZNY FENOMEN SUBKULTURY STILIAGÓW}

Nazwa pierwszej radzieckiej subkultury młodzieżowej pochodzi od słowa styl (стиль) i jest związana z jednej strony z modnym ubiorem, z drugiej - ze stylem tańca, niezwykle istotnym w życiu stiliagów. „Tańczyć stylem” oznaczało praktykować „zakazane” w kraju tańce, przypominające boogie woogie. Styl tańca wiązał się z opanowaniem trzech technik ukrytych pod nazwami: atomowy, kanadyjski, potrójny hamburski (атомный, канадский, тройной гамбургский) ${ }^{6}$. Pośród tańców oficjalnie dozwolonych, jak walc czy polka, frywolne ruchy młodzieży budziły zgorszenie, szczególnie w trakcie szkolnych i studenckich imprez młodzieżowych. Historia powstania pierwszej radzieckiej subkultury młodzieżowej sięga pierwszych lat po zakończeniu II wojny światowej. Z okresem tym wiąże się nowe spojrzenie na adolescencję, postrzeganą do tej pory jako krótki okres wzrostu i oczekiwania na pełnienie funkcji w świecie dorosłych. Młodość, uważana za okres przejściowy, związany z wiekiem i rozwojem biologicznym człowieka, od początku lat 50. zyskała samoistną wartość jako odrębny „fakt kulturowy" . Sławkin pisze o tym następująco: I tak po raz pierwszy w historii naszego państwa mtodzież początku lat pięćdziesiątych odczuta swoje życie nie jako jedno ze stadiów rozwoju sowieckiego cztowieka, ale jako oddzielna, samodzielna i zamknięta egzystencję (Памятник..., s. 48).

Ze zjawiskiem tym korespondowała chęć odróżnienia się od pokolenia rodziców, bunt wobec stylu życia, światopoglądu i metod działania starszych przedstawi-

5 Na ten temat zob.: K. Duda, Między realizmem a postmodernizmem. Generation P Wiktora Pielewina, „Slavia Orientalis” 2004, nr 2, s. 207-217; A. Dudek, Między groteską a rzeczywistościq wirtualną. Wiktor Pielewin Generation P, [w:] Humanistyka slawistyczna dziś. Nowe spojrzenie i stanowiska, red. L. Suchanek, Kraków 2005, s. 71-84, Prace Komisji Kultury Stowian PAU, 4.

6 А. Козмов, Козём на саксе, [online] http://www.musiclab.ru, 30 I 2014.

7 Na ten temat zob.: T. Bąk, Wspótczesne uwarunkowania kreacji subkultur mtodzieżowych, Warszawa 2008, s. 16-19; P. Piotrowski, Subkultury mtodzieżowe. Aspekty psychospoteczne, Warszawa 2003, s. $12-14$. 
cieli społeczeństwa, najczęściej żarliwych wyznawców komunizmu i kultu jednostki. Wydarzenia związane ze śmiercią Stalina, następnie XX Zjazd KPZR oraz okres chruszczowowskiej odwilży umocniły pozycję młodzieży, umożliwiając pojawienie się szeregu zjawisk włączanych do kultury młodzieżowej. Jej rozwój zarówno w krajach Europy Zachodniej, jak i na terenie Związku Radzieckiego jest odbiciem skomplikowanych procesów społecznych i zmian cywilizacyjnych. Młodzież świadomą własnej odrębności charakteryzowała nasilona potrzeba autonomii oraz sprzeciw wobec zastanego modelu egzystencji. Na terenie państw bloku wschodniego zjawisko kultury młodzieżowej z jej nieodłącznym elementem kontestacji przeszło o wiele bardziej skomplikowaną drogę, utrudnioną z powodu monopolu władzy obejmującego także szeroko pojęte procesy kulturotwórcze. Kontrola władzy nad wszystkimi aspektami życia społecznego, artystycznego i politycznego zmierzała do stworzenia jednolitej masy podobnie myślących ludzi, zamkniętych w ramach „poprawności” ideologicznej. Najmniejszy przejaw odmienności rodził podejrzenia ze strony reszty społeczeństwa i prowokował władze do zastosowania odpowiednich kroków celem skierowania „odmieńca” na właściwy tor myślenia. Sprzyjała temu szeroko zakrojona propaganda, promująca jedyną słuszną drogę ku świetlanej przyszłości oraz pożądany obraz członka radzieckiego społeczeństwa.

W przedstawieniu fenomenu stiliagów należy uwzględnić fakt, iż był on częścią ogólnoświatowego trendu w młodzieżowych ruchach kontrkulturowych. Zjawisko to zostało określone mianem "pokolenia '52”, czerpiącego inspirację od amerykańskich mniejszości kolorowych, ich stylu ubioru i postawy życiowej (zoot suit $)^{8}$. W jego ramach mieściły się takie ruchy młodzieżowe, jak: teddy boys w Wielkiej Brytanii, bikiniarze w Polsce, malagambiści w Rumunii czy stiliagi w ZSRR. „Amerykańska gorączka” owładnęła także młodzież z Włoch, Czechosłowacji, Szwecji, Niemiec i Danii'. Spoiwem łączącym „pokolenie '52” była muzyka jazzowa i moda młodzieżowa, a także swoisty stosunek do wielobarwnej kultury Stanów Zjednoczonych. Zdaniem Aleksandry Matyukhiny sowieccy zwycięzcy przynieśli z gtębi Europy nowe idee, wiedzę o nieznanej kulturze. Zobaczyli, że żyć można inaczej i lepiej ${ }^{10}$. Źródłem wiedzy mieszkańców ZSRR o kulturze Zachodu stali się byli uczestnicy wojny, a także coraz liczniejsi przedstawiciele zagranicznych ambasad i konsulatów. O kanałach dostępu do wiedzy o zachodniej kulturze rozrywkowej pisał także aktywny członek subkultury stiliagów Aleksiej Kozłow ${ }^{11}$ : zgromadzitem kolekcję wspótczesnych ptyt, przywiezionych z Niemiec przez wracajacych z wojny ojców dzieci mojego pokolenia. To byt prawdziwy amerykański jazz wykonywany przez orkiestre Glenna Millera i Benny'ego Goodmana ${ }^{12}$.

8 M. Chłopek, Bikiniarze. Pierwsza polska subkultura, Warszawa 2005, s. 11.

9 Tamże, s. 69-76.

10 A. Matyukhina, W sowieckim Lwowie. Życie codzienne miasta w latach 1944-1990, Kraków 2000, s. 96.

11 Kozłow brał czynny udział w muzycznym opracowaniu spektaklu Dorosta córka..., wnosząc wiele historii znanych z autopsji. Zob.: B. САавкин, Памятник..., s. 222-223.

12 А. Козмов, Козёл на саксе... 
Pojawienie się w większych miastach europejskiej części ZSRR młodych „stylowych" ludzi (we własnym języku określali siebie jako чуваки і чувихи ${ }^{13}$ ), eksponujących własną odrębność kulturową, stanowiło wyraźne wyzwanie i prowokację wobec ówczesnego społeczeństwa. Młodzież, szczególnie jej męska część, wyróżniała się przede wszystkim ekstrawaganckim stylem ubierania: wąskie, opinające nogi spodnie sięgające ponad kostki (Аудочки), ukazujące bajecznie kolorowe skarpety, szerokie welwetowe marynarki, barwne krawaty ze śmiesznymi wizerunkami, buty na grubej podeszwie (на манной каше) oraz długie płaszcze, kapelusze i białe szaliki. Najbardziej pożądane części garderoby pochodziły ze Stanów Zjednoczonych. Młodzież zadowalała się również odzieżą rodzimej produkcji zręcznie przerabianą przez zaprzyjaźnionego krawca. Zaskoczenie budziła także fryzura stiliagów - charakterystyczne „czuby” („коки” - starannie ułożona fala włosów nad czołem, schodząca na kark), pojawiające się wbrew panującej modzie na „fryzurkę polityczną” („политический зачес”), a więc starannie ostrzyżone włosy bez fal i kosmyków opadających na szyję lub czoło.

Moda i fryzura kobiet wymagały większych wysiłków, a przede wszystkim psychicznej odporności na szykany ze strony reszty społeczeństwa ${ }^{14}$. „Stylowe” dziewczęta nakładały kolorowe, dużo krótsze niż przyjęto spódnice z rozcięciem, nylonowe pończochy „ze szwem” oraz obcisłe bluzki. Charakterystyczne były także buty na wysokim obcasie. Zimą najbardziej odważne członkinie tej subkultury przywdziewały spodnie. Dziewczęta czesały włosy w koński ogon, fantazyjnie spięty wysoko na czubku głowy, lub strzygły się na krótko („węgierka”, „венгерка”). Dodatkowo nieodłącznym atrybutem kobiet był mocny makijaż z podkreślonymi pomadką ustami oraz jaskrawo pomalowane paznokcie. Ubiór stanowił nie tylko chęć naśladowania amerykańskiego stylu, ale był też pewną formą oporu wobec radzieckiej szarzyzny i monotonii. Przywiązywanie wagi do poszczególnych elementów stroju wyrażało pragnienie estetyzmu i wyczucia dobrego smaku, a także potrzebę manifestacji indywidualizmu i oporu wobec rzeczywistości ${ }^{15}$.

Obok stroju i fryzury niezwykle ważny był styl życia, którego wyznacznikiem były muzyka i taniec. Wielkim uznaniem w gronie stiliagów cieszył się właściciel oryginalnych płyt gramofonowych, które w owych czasach można było zdobyć m.in. od spekulantów (фарцовщики) za bajecznie wysokie sumy. Pozostali zadowalali się kopiami tworzonymi metodą chałupniczą na kliszach rentgenowskich, stąd określenia: „muzyka na kościach”, „jazz na żebrach”, „kolekcja szkieletowa”. Zakazanej muzyki radziec-

13 Czuwaki, czuwichy - wyrażenie slangowe. Nieprzetłumaczalne na język polski.

14 Kozłow odnotowuje, że żeńska część subkultury stiliagów stanowiła mniejszość, czego powodów należy doszukiwać się w zbyt dużej presji społeczeństwa na „dziewiczy” wizerunek radzieckiej niezamężnej kobiety. Wygląd i zachowanie członkiń tej subkultury w oczach społeczeństwa wiązały się z wizerunkiem kobiety „lekkich obyczajów”. Społeczną dezaprobatę, szykany i represje znosiły jedynie niezależne i silne psychicznie jednostki. Zob.: A. Козмов, Козёл на саксе...; К. Рот-Ай, Кто на пьедестале, а кто в толпе? Стиляги и идея советской „молодежной культуры” в эпоху „оттепели”, „Неприкосновенный запас" 2004, nr 4, [online] http://magazines.russ.ru/nz/2004/4/ra4-pr.html, 5 II 2014.

15 M. Chłopek, Bikiniarze..., s. 97. 
cy pasjonaci słuchali w domowym zaciszu, zwykle pod nieobecność rodziców. Rzadką tradycją były wieczorne spotkania w większym gronie w mieszkaniu jednego z młodzieńców („domówki” -квартирники, w slangu - „chaty”, „хаты”), na których królowała zachodnia muzyka, „stylowe” tańce i zagraniczne napoje alkoholowe. Stiliagów charakteryzowała stosunkowo duża jak na owe czasy swoboda obyczajowa w relacjach damsko-męskich. Przy czym, jak zaznacza słynny saksofonista i jazzman Kozłow, model stosunków między przeciwnymi płciami opierał się na partnerstwie, przyznając obu stronom równe prawa ${ }^{16}$.

Wyzwolenie, również na gruncie seksualnym, a także rozrywkowe podejście do życia były obiektem surowej krytyki ze strony władzy i mediów. Do obiegu społecznego szybko weszły slogany krytykujące styl życia stiliagów i jazz, pośród nich najbardziej znane: dzisiaj tańczy/gra jazz, a jutro zdradzi ojczyzne [сегодня он танцует/играет Ажаз, а завтра родину продаст $]^{17}$. Na straży moralności stały szeregi rówieśników, pionierzy i komsomolcy, dobrowolnie patrolujący ulice i oficjalne miejsca potańcówek młodzieży (комсомольские патрули). Wygląd i zachowanie młodzieży zafascynowanej Zachodem rodziły wyjątkową wrogość komsomolskich oddziałów. Akty nienawiści sprowadzały się do napaści na stiliagów, niszczenia ich ubrań, przycinania „czubów”, a nawet dotkliwych pobić i fizycznego znęcania się nad młodzieżą. Stiliagi stanowili także czujny obiekt obserwacji milicji i grup rodziców, wizytujących wieczorki taneczne dla młodzieży. Podczas szkolnych zabaw nad czystością i przestrzeganiem norm w zachowaniu czuwali także nauczyciele, postępujący zgodnie z instrukcjami Rejonowych Oddziałów Edukacji Narodowej (Районные Отделы Народного Образования, РОНО). Odgórnie narzucony styl życia sprowadzał się również do dbałości o rodzaj tańca i muzyki słuchanej na szkolnych imprezach. Prowokacje członków subkultury, polegające na zamianie „dozwolonych” płyt na „muzykę kapitalistów i wyzyskiwaczy”, oraz próby tańczenia „stylem” zwykle prowadziły do szybkiego zakończenia szkolnych potańcówek.

Jednak na „odmieńców” czyhały także bardziej srogie kary: wykluczenie ze szkoły, z organizacji komsomolskiej, zwolnienie z pracy. Model życia nieprzystający do reszty społeczeństwa powodował ostracyzm społeczny, szykany i obelgi na ulicy, w szkole i pracy. Kozłow wyjaśnia kampanię społeczną przeciw stiliagom w następujący sposób: Przeciętnego sowieckiego cztowieka nie trzeba byto specjalnie agitować przeciw mtodym ludziom, którzy wewnętrznie i zewnętrznie nie chcieli być podobni do reszty. Gtównym sposobem na to, by odróżnić się od ttumu, byty „stylowe”: odzież, fryzura, sposób chodzenia, taniec, żargon. Dlatego pojawito sięstowo „stiliaga”, przypominajace równie nieprzyjemne: "dochodiaga”, „brodiaga”, „biedniaga” itp. ${ }^{18}$

Zdaniem Kristiny Roth-Ey Stiliazestwo nie istniato w kodeksie karnym, dlatego byto traktowane jako „, antyspoteczny stosunek do życia”. Jednak tych, których określano mianem

16 А. Козцов, Козёл на саксе...

17 V. Tarnavskyi, Dzieci swoich czasów. Ruchy mtodzieżowe w Rosji a zmiany kulturowe po upadku ZSRR, Warszawa 2007, s. 107. Autor zaznacza, iż nagonkę na muzykę jazzową rozpoczęto w 1946 r., a jej w wyniku aresztowano wielu muzyków.

18 А. Козмов, Козёл на саксе... 
„stiliagów", tapano, a następnie prowadzono przed oblicza wtadz miejscowego Komsomotu lub prosto do oddziatów milicji; przymusowo strzyżono, zabierano lub niszczono ubrania, fotografowano, a następnie zdjęcia umieszczano $w$ prasie $w$ rubryce "Oni hańbia nasze miasto"19.

Kampania przeciw stiliagom była podsycana w oficjalnych organach prasowych, wśród których pod względem ilości materiałów o „wrogiej” młodzieży prym wiodty: „Krokodyl” („Крокодик”), „Prawda” („Правда”), „Komsomolska Prawda” („Комсомольская правда”). Nieprzypadkowo termin „stiliaga” został niechlubnie rozpowszechniony na łamach satyrycznego czasopisma „Krokodyl” w 1949 r. przez Dmitrija Bielajewa, który w rubryce Typy odchodzace do przesztości (Типы, уходящие в прошиое) zamieścił felieton zatytułowany Stiliaga (Стиляга) ${ }^{20}$. W ironicznym tonie autor opisywał modę członków subkultury, język, styl zachowania i tańca. Dodatkowo teksty były ozdabiane karykaturalnymi rysunkami przedstawicieli „wrogiego elementu”, co, paradoksalnie, sprzyjało popularyzacji wizerunku subkultury w kręgach niezależnej młodzieży.

Gazeta „Prawda” charakteryzowała się bardziej surowym tonem względem zjawiska, agitując społeczeństwo do walki z wszelkimi przejawami „burżuazyjnego” życia i charakteryzując członków subkultury jako próżniaków, pijaków i potencjalnych zdrajców. Kozłow wspomina, iż w jednym z numerów dziennika pojawił się artykuł o studenckim wieczorku tanecznym stiliagów pod tytułem Pleśń. Muzyk komentuje ten fakt: od tego czasu stowo "pleśn" $i$ „stiliaga" staty sie synonimami w świadomości spoteczeństwa ${ }^{21}$.

Społeczną wrogość rodziły także spontaniczne akcje happeningowe stiliagów, odbywające się na ulicy Gorkiego (w slangu stiliagów: Broadway - БроА, Бродвей). Polegały one na przechadzaniu się w rytmie swinga kolumn stiliagów w jedną stronę, a następnie zawracaniu i powtarzaniu tej czynności. Inną formą manifestacji było wybieranie przypadkowego przechodnia, a następnie ustawianie się za nim i naśladowanie jego ruchów. Zabawa kończyła się, kiedy „ofiara” orientowała się w sytuacji lub interweniowała milicja. Niecodzienny widok tych wieczornych manifestacji wzmagał fakt, iż druga strona ulicy była zapełniona przez zwykłych mieszkańców miasta. Viktor Tarnavskyi przekonuje, że jedna z podstawowych funkcji „Broadwayu” polegała na zawieraniu znajomości między samymi stiliagami, z czym wiązało się wspólne spędzanie wolnego $\mathrm{czasu}^{22}$. Podobne miejsca znajdowały się w większych miastach Związku Radzieckiego: w Leningradzie - Newski Prospekt, w Kazaniu - ulica Baumana, w Niżnym Nowogrodzie - Bolszaja Pokrowskaja, w Permie - Komsomolskij Prospekt. Kozłow pisze o tradycyjnym miejscu spotkań stiliagów z dużym sentymentem, nadając mu istotne znaczenie w rodzącej się kulturze młodzieżowej: faktycznie, tutaj nieustannie funkcjonowat uliczny klub, odgrywajacy bardzo ważna rolę w życiu Moskwy ${ }^{23}$.

19 К. Рот-Ай, Кто на пьедестале...

20 Na ten temat zob.: A. Козцов, Козёл на саксе...; В. Славкин, Памятник..., s. 39-41.

21 А. Козцов, Козём на саксе...

22 V. Tarnavskyi, Dzieci swoich czasów..., s. 106.

23 А. Козцов, Козём на саксе... 
Radziecką młodzież skupioną wokół zachodniej kultury cechowały indywidualność, chęć wyróżnienia się z szarej masy i wolność osobista. Był to pierwszy masowy przejaw młodzieżowego nonkonformizmu, który uwidaczniał się zarówno na poziomie poglądów, jak i specyficznych praktyk i zachowań symbolicznych ${ }^{24}$. Wydaje się, iż swoją epokową rolę docenili także sami członkowie subkultury, uznając się za pierwszych radzieckich dysydentów ${ }^{25}$. Większość badaczy radzieckich subkultur podchodzi jednak do dysydentyzmu stiliagów z ostrożnością, nazywając ich pionierami nieoficjalnej kultury, pierwszym przejawem wolności osobistej i indywidualizmu w ZSRR, prowokatorami rzucającymi wyzwanie szarości dnia powszedniego ${ }^{26}$. O fakcie inakomyslija stiliagów świadczą ich pozamuzyczne zainteresowania: „zakazane” i niedostępne w ZSRR amerykańskie filmy, literatura czy awangardowe malarstwo zachodnie. Mimo grożących sankcji słuchali Głosu Ameryki i BBC. Kozłow wspomina, iż dzięki znajomościom ze stiliagami otrzymał dostęp do dzieł rodzimych twórców będących „na indeksie”, takich jak: Anna Achmatowa, Michaił Zoszczenko, Borys Pilniak, Izaak Babel, Jewgienij Zamiatin ${ }^{27}$. Trudno jednak mówić o świadomej dysydenckiej działalności tej części młodzieży. W większości podążali za modą panującą w ich towarzystwie, starali się być bardziej „stylowi” poprzez „nielegalny” styl życia. Prawdopodobnie nie zdawali sobie do końca sprawy z siły represji, na jakie narażają się wszyscy członkowie radzieckiego społeczeństwa decydujący się żyć poza ramami oficjalnej ideologii. Wielu z nich chronił także ojcowski immunitet, jak bowiem wspomina Kozłow: w gronie „ztotej mtodzieży" byli także ludzie catkiem niedostepni - dzieci partyjnych pracowników, znanych dziataczy kultury i nauki ${ }^{28}$.

Sławkin w obu sztukach oraz w Pomniku... szkicuje romantyczną wizję stiliagów, jednak daleki jest od włączenia tej subkultury do ruchu dysydenckiego. O romantyce ruchu świadczy refleksja autora nad piosenką Chattanooga Choo Choo (w slangu stiliagów $c z u c z a$-Чучa), wykonywaną przez orkiestrę Millera w filmie Serenada w Dolinie Stońca (Sun Valley Serenade, 1941). Chattanooga stała się symbolem nadziei na lepsze życie, marzeniem o raju na ziemi: to miasto nie byto wtedy dla nas jedynie nazwa geograficzna; w tym stowie mieścity się wszystkie nasze marzenia o przysztym życiu, wszystko, co osiagnie nasze pokolenie... (Памятник..., s. 45-46). Pociag do Chattanoogi był symbolem wiary w nieograniczone możliwości pokolenia, które przeżyło wojnę i nie bało się marzyć o przyszłości.

Ruch stiliagów, jak podobne ruchy młodzieżowe w Europie, nie trwał długo. Subkultura zaczęła powoli wygasać z chwilą utraty elitarności, kiedy do ruchu zaczęła przyłączać się młodzież z rodzin robotniczych i mniejszych miast. Ponadto odwilż Chrusz-

24 V. Tarnavskyi, Dzieci swoich czasów..., s. 108.

25 В. Аксенов, В поисках грустного беби, Москва 2000, s. 20. O stiliagach jako pierwszych radzieckich dysydentach pisze socjolog Leonid Ionin. Zob.: $\Lambda$. Ионин, Социология культуры: путь в новое тысячеметие, Москва 2000, s. 176.

26 Zob. m.in.: V. Tarnavskyi, Dzieci swoich czasów..., s. 107-108; А. Троицкй, Рок в Союзе: 60-е, 70-е, 80-е, Москва 1991, s. 9-15.

27 А. Козмов, Козёл на саксе...

28 Tamże. 
czowa wpłynęła na liberalizację poglądów również w odniesieniu do kultury świata zachodniego, a radzieccy dygnitarze przestali postrzegać amerykański styl życia jako absolutne zło. W tym kontekście znaczące wydają się słowa Aksionowa, wielokrotnie przytaczane przez Sławkina: Trzeba byto dwudziestu lat, by zrozumieli, że coca-cola to tylko lemoniada i nic więcej (Памятник..., s. 98). Pierwszą konfrontacją radzieckiej młodzieży z przedstawicielami krajów „zza żelaznej kurtyny” był Festiwal Młodzieży w Moskwie w 1957 r. ${ }^{29}$ Spotkanie z młodzieżą amerykańską uświadomiło znacznej części stiliagów, iż nie są w żaden sposób podobni do młodych ludzi z Nowego Świata ${ }^{30}$. W drugiej połowie lat 50 . subkultura stiliagów zanikła, jednak nadal pozostaje inspiracją dla wspomnień i refleksji nad przeszłością oraz obiektem badań socjologicznych i kulturoznawczych.

\section{KULTUROWY FENOMEN SUBKULTURY STILIAGÓW (DOROSEA CÓRKA MEODEGO CZEOWIEKA)}

Sztuka Wiktora Sławkina Córka stiliagi (Дочь стиляги) powstała w 1972 r. i, jak twierdzi jej autor, za sprawą samego tytułu miała dokonać rehabilitacji terminu „stiliaga” (Памятник..., s. 78-79). Jednak z chwilą pojawienia się możliwości wystawienia dramatu na deskach teatru za radą Aksionowa autor zmienił tytuł na bardziej neutralny Dorosta córka mtodego cztowieka. Ostatecznie w 1979 r. spektakl znalazł się w repertuarze Teatru im. Stanisławskiego, co wiązało się ze zmianą kursu w dramaturgii radzieckiej. Obok debiutów dramaturgów piszących dotąd „do szuflady” (Ludmiła Pietruszewska, Władimir Arro, Aleksander Galin) na oficjalną scenę wyszli także młodzi reżyserzy z nowatorską wizją radzieckiego teatru (Anatolij Wasiliew, Mark Zacharow, Iosif Reichelgaus). Współpraca dramaturgów, natchnionych twórczością Sławomira Mrożka i Eugene’a Ionesco, z młodymi inscenizatorami zaowocowała odrzuceniem stereotypów dramaturgii „socjologicznej” i krytycyzmem wobec schematów socrealizmu. Cechą łączącą dramaturgów „nowej fali” była manifestacja nastrojów pesymistycznych oraz próba zdiagnozowania sytuacji współczesnego człowieka w wymiarze społecznym i egzystencjalnym ${ }^{31}$. Pojawiły się nowe tematy, nowi bohaterowie i nowe idee, a także, co ważniejsze, nowa intonacja - odarta z patosu, przybliżająca bohatera do widza.

U podstaw fabuły dramatów „nowej fali” leży trywialne wydarzenie, epizod z życia, stanowiący powód do rozmyślań nad własnym stanem duchowym i otaczającą rzeczywistością. W sztuce Sławkina impulsem do refleksji jest pozornie niewiele znaczące spotkanie (po dwudziestu latach) kolegów ze studiów. W dwupokojowym mieszkaniu Kuprianowa spotykają się: Bems, Prokop, Iwczenko oraz żona Bemsa Lusia, w przeszłości piosenkarka kina Orion. Pierwszy akt jest w całości poświęcony wspomnieniom o latach studenckich, z których najważniejsze dotyczą uczestnictwa w ruchu stiliagów.

29 Zob. więcej: П. Вайль, А. Генис, 60-е. Мир...

30 M. Chłopek, Bikiniarze..., s. 69.

31 Historia literatury rosyjskiej..., s. 524. 
Temat, kreacje aktorskie i nowatorska odsłona znalazły uznanie w oczach widzów, o czym świadczy liczba wystawionych spektakli, a także telewizyjna adaptacja sztuki pod tym samym tytułem, zrealizowana w latach 1981-1982 ${ }^{32}$.

Wraz z przypływem „nowej fali” odeszła w przeszłość dramaturgia bohaterów pozytywnych. W ich miejsce pojawiły się postaci ludzi niezadowolonych z dotychczasowego życia, sfrustrowanych konformistów naznaczonych duchową ospałością ${ }^{33}$. W ten kanon portretowania wpisuje się Bems ze sztuki Sławkina. Bohater unika wspomnień z lat studenckich, kiedy wiódł nonkonformistyczne życie stiliagi. Jego młodość była pełna wzniosłych ideałów i marzeń, których sens oddawały słowa piosenki Chattanooga Choo Choo, wielokrotnie nuconej przez bohaterów. Egzystencję Kuprianowa wypełnia pustka i monotonia. Stan duszy Bemsa oddają słowa jego żony: życie, jak widzicie, nie udato się $^{34}$. Spotkanie po dwudziestu latach, z charakterystycznym dla tego typu wydarzeń podsumowaniem zysków i strat, staje się dla bohatera udręką, niepotrzebnym powrotem do przeszłości.

Poczucie życiowej pustki wzmaga przybycie Iwczenki, w latach 50. aktywnego członka komsomolskich brygad prowadzących walkę z młodzieżą o zachodnioeuropejskiej orientacji. Obecnie prorektora uczelni, eleganckiego mężczyzny, mającego liczne kontakty w gronie radzieckiej „wierchuszki” i na Zachodzie. Lata 70. uważa za czas dobrobytu i nowych możliwości: Trzeba żyć! Panowie, rozejrzycie się wokót, wszystko jest inne! Kraj się zmienit - żyjemy w Żiguli-land! (Взрослая дочь..., s. 102). Na spotkanie przybywa w radosnym nastroju, chętnie opowiada o swym dostatnim życiu, nie przejawiając negatywnych uczuć w stosunku do byłych oponentów. Wspomnienia z lat młodości wywołują na jego twarzy pobłażliwy uśmiech: To byty czasy! Śmiesznie wspominać... Na jazz rzucali sie jak byki na czerwone (Взрослая дочь..., s. 26). Stara się zrozumieć motywy postępowania stiliagów, wniknąć w ich logikę myślenia sprzed dwudziestu lat. Rozdrażnienie Bemsa budzi fakt, iż jego młodzieńcze niezrealizowane marzenia urzeczywistniły się w dojrzałym życiu byłego komsomolca. Iwczenko ma dostęp do zagranicznej literatury i muzyki, uczestniczy w towarzyskim i kulturalnym życiu wielu stolic Europy, a co najważniejsze - w trakcie swoich podróży dotarł do miasta-raju stiliagów: Chattanoogi w stanie Tennessee. Bems nie ukrywa złości, którą potęguje miłosna intryga Lusi i Iwczenki.

W dramacie pojawiają się dwa rodzaje konfliktów: tradycyjny (zewnętrzny) - bohater występuje przeciw innemu bohaterowi (Bems-Iwczenko), oraz wewnętrzny - bohater występuje przeciw samemu sobie i swojemu życiu. Drugi typ konfliktu jest charakterystyczny dla dramaturgii „nowej fali”. Uwypuklona linia podziału w dramacie Sławkina przebiega nie między bohaterami, a wewnątrz nich. Olga Bagdasarian wskazuje także na linię prozaiczną (прозаическая интонация) і liryczną (кирическая

32 O popularności utworu Sławkina świadczy fakt, że w 1992 r. nakręcono dwuczęściowy film Droga do Chattanoogi (Аорога на Чаттанугу), w którym obok aktorów znanych z wersji teatralnej wystąił Sława Nadieżdin (alter ego Bemsa). Sławkin jest także autorem monologu Prokopa, który w wykonaniu aktora Aleksandra Filipienki zdobył ogromną popularność w teatrze i telewizji.

33 Historia literatury rosyjskiej..., s. 524.

34 В. Славкин, Взрослая дочь молодого человека, [w:] tenże, Памятник..., s. 12. 
интонация $)^{35}$. Intonacja prozaiczna charakteryzuje Iwczenkę, ironicznie upraszczającego minione lata konfliktów, próbującego rozwiązać niepojętą dla niego „zagadkę stiliagów”. Jednocześnie bohater stara się sprowadzić Bemsa „na ziemię”: Nieudaczniku! Jesteś zwyktym starym nieudacznikiem. Co ci przeszkadzato nim nie zostać? Pamiętam cię przecież, ryzykanta, który nas pouczat, wszystko wiedziat o przysztości, o życiu, o sztuce... I oto nadeszta przysztość. A gdzie twoje ryzyko? Caty odszedteś w swoja „czucze”? (Взрослая дочь..., s. 98).

Kuprianow reprezentuje linię liryczną. Jest uwikłany we wspomnienia o przeszłości, nie potrafi znaleźć dla siebie miejsca w życiu teraźniejszym. Bemsa, obok nostalgii, charakteryzuje egocentryzm, wyrażający się w braku zrozumienia potrzeb żony, problemów córki i wyzwań współczesnego świata: Jesteś ślepy! Nic nie widzisz poza swoją „czucza”. Dlaczego nie odpuszcza cięprzez tyle lat? Ona nie daje ci żyć (Взрослая дочь..., s. 244). Bohater jest postacią tragiczną, znajdującą się na dnie życiowej pustki, w której tkwi także jego żona.

Nabierający siły konflikt Bemsa i Iwczenki łagodzi postać Prokopa, niegdyś uczestniczącego w życiu „stylowej” młodzieży stolicy. Dla bohatera lata studenckie są miłym wspomnieniem: A dla mnie tamte czasy - święto! Najlepsze pięć lat mojego życia (Взрослая Аочь..., s. 27). Młodość traktuje jako zamknięty rozdział, do którego należy wracać we wspomnieniach i rozmowach z przyjaciółmi. Jednocześnie Prokop dobrze odnajduje się w realiach współczesnego życia, przejawiając stosunkowo prostą filozofię: Jestem spokojny dlatego, że zajmuje swoje miejsce. Ptywam i ptywam... (Взроская АОчь..., s. 293). Zdystansowany stosunek do samego siebie pozwala mu wieść spokojną egzystencję w Czelabińsku, pozostając na uboczu stołecznych wydarzeń. Lata młodości wiódł w cieniu Bemsa, podświadomie ulegając fascynacji kulturą Zachodu. Groteskowość postaci prowincjusza uwypukla fakt, iż w gościnę przybył z torbami deficytowych towarów niedostępnych w Czelabińsku. Jednak podróż Prokopa do stolicy ma także prywatny charakter: pragnie umówić się na rozmowę z prorektorem Iwczenką w celu umożliwienia swojemu synowi podjęcia studiów technicznych. Złość wobec dawnego oponenta z Komsomołu minęła bezpowrotnie, zamieniając się w uniżony stosunek do przedstawiciela „władzy”.

Drugi akt sztuki wprowadza nowe konflikty, nowe postaci i nowy kontekst odczytania psychologicznego rysu Bemsa i jego gości. Pierwszoplanowych bohaterów, uniesionych we wspólnym tańcu boogie woogie, zastaje córka Kuprianowów Ella (na czesśc Elli Fitzgerald), studentka uczelni prorektora Iwczenko. Wygląd dziewczyny świadczy o przynależności do ruchu hipisów, a wianek na głowie i bukiet kwiatów w rękach nasuwają myśl, iż uczestniczyła w happeningu, o którym z oburzeniem opowiadał Iwczenko, złowrogo wieszcząc o planach skreślenia buntowników z listy studentów. Pojawienie się Elli wprowadza tradycyjny w rosyjskiej literaturze temat konfliktu pokoleń i bariery, jaka istnieje między ojcami i dziećmi. Niezrozumiałe zachowanie córki, problemy na uczelni i jej beztroski stosunek do życia stają się impulsem do zrewidowania własnych

35 О. Багдасарян, Взрослая дочь молодого человека $u$ Памятник неизвестному стиляге B. Славкина: поколение 1950-х в эпоху застоя, „Политическая мингвистика” 2010, nr 3, s. 134. 
poglądów. Bems stara się wniknąć w światopogląd młodej hipiski, w czym przypomina Iwczenkę, próbującego po latach zrozumieć fenomen stiliagów. Pierwsza próba nawiązania kontaktu z Ellą zabarykadowaną w swoim pokoju kończy się klęską - Kuprianow omdlewa pod wpływem nagłego bólu serca. Trwoga o ojca skłania młodą kontestatorkę do głębszych wyznań, które pozwalają na zawarcie przymierza z rodzicami: Nie wiedziatam, że mam takiego mtodego ojca - tańczy i śpiewa, To co, zapoznamy się? (Взрослая дочь..., s. 175). Dłoń Elli, wyciągnięta w geście pojednania, burzy barierę międzypokoleniową, czego kwintesencją jest wspólny taniec w rytmie „czuczy”.

Powyższa problematyka skłania do postawienia tezy: każde pokolenie ma swoich „...diesiatników”: „szestidiesiatników”, „siemidiesiatników”, „wosmidiesiatników” itd. ${ }^{36}$ Pod tym względem Rosja niewiele różni się od krajów Europy Zachodniej: pokolenie dzieci, przeżywające okres kontestacji względem pokolenia ojców, zwiera szeregi w celu zaprezentowania własnego światopoglądu, własnego sposobu na życie, własnej drogi do szczęścia. Bunt młodzieży ma miejsce w granicach konfliktu pokoleń, choć doświadczenia lat 60. ubiegłego wieku w krajach kapitalistycznych pokazały, że może on prowadzić do powstania szerokiego ruchu społecznego skierowanego przeciw aparatowi władzy i środkom manipulacji, kwestionującego ekonomiczne, społeczne i kulturowe osiągniecia minionych lat ${ }^{37}$. Dla młodego, zbuntowanego pokolenia „siemidiesiatników”, którego przedstawicielami w sztuce Sławkina są Ella i jej przyjaciel Igor, świat ojców jawi się jako niedorzeczny, zbyt skomplikowany i nieprzystający do współczesnego. Hipiskę śmieszy spotkanie „starych przyjaciół”, ich pełne nostalgii wspomnienia, tańce, piosenki. Mimo że jest uczestnikiem subkultury młodzieżowej, początkowo nawet nie stara się zrozumieć naczelnej idei, jaka przyświecała stiliagom. Drażni ją „,masowość” ruchu, zanik indywidualizmu, poczucie braterskiej więzi ze wszystkimi podobnie myślącymi: on (ojciec) nigdy nie będzie sam, zawsze będzie z innymi. Nigdy nie spotka się z kimś „twarzą w twarz” (Взрослая дочь..., s. 168). Konflikt widoczny jest także wśród siemidiesiatników. Ella i Igor wyśmiewają ideały Toli Prokopowicza: To wszystko gtupstwa, zrozumiateś, gtupstwa! Twój instytut i dyplom, wszystko gtupstwo! Pyt! (Взрослая дочь..., s. 163). Historia zatoczyła koło, kolizja marzeń i ideałów wśród „generacji dzieci” przywodzi na myśl tożsamą sytuację w gronie pokolenia lat 60. (Bems-Iwczenko). Ostatecznie wspólne wyjście do kina Orion łagodzi wszelkie spory, godząc pokolenia kolejnych „...diesiatników”.

Gdy przyglądamy się kulturowemu portretowi pierwszej radzieckiej subkultury, na pierwszy plan wysuwa się nostalgiczno-sentymentalny charakter opisu. Sławkin jako jeden z pierwszych twórców uwypuklił romantyczny obraz środowiska moskiewskich

36 Oleg Dark podkreśla trudności językowe z terminem określającym pokolenie lat 90.: Аевяностник(и) просто непроизносимо. Jednocześnie zwraca uwagę na fakt, iż pokolenie to nie istnieje, funkcjonuje jedynie jako generacja, a więc ludzie, których łączy data narodzin w tym samym dziesięcioleciu. Zob.: О. Аарк, Крушение космоса, „Неприкосновенный запас” 1999, nr 2, [online] http://magazines. russ.ru/nz/1999/2/dark-pr.html, 8 II 2014.

37 Zob.: A. Jawłowska, Drogi kontrkultury, Warszawa 1975, Biblioteka Myśli Wspótczesnej. 
stiliagów. Ten efekt osiągnął poprzez konfrontację marzeń byłych stiliagów z ich dojrzałością przypadającą na czasy Breżniewowskiego zastoju. Pomnik nieznanego stiliagi jest ciekawym dopełnieniem dramatu. Jednak we wspomnieniach mit przeszłości dominuje nad pozostałymi wątkami, tworząc wyidealizowany obraz, odległy od rzeczywistości. Podobnie w opisie lat młodzieńczych innego uczestnika ruchu, Kozłowa, subkultura stiliagów jest barwnym wspomnieniem powojennego pokolenia, dalekim od rzeczywistości.

W tonie nostalgicznym o pierwszych radzieckich nonkonformistach pisał także Aksionow w książce $W$ poszukiwaniach smutnego baby. Warto odnotować, że pisarz w młodości był członkiem subkultury stiliagów, a jako twórca prozy młodzieżowej opisywał naiwną pogoń za "gwiaździstym biletem”, czyli szansą spełnienia marzeń ${ }^{38}$. Ciekawym spojrzeniem na wyidealizowany obraz młodości jest opowiadanie przedstawiciela młodszej generacji Andrieja Giełasimowa. Ziganszyn boogie (Зиганшин-буги, 2004) to historia trojga stiliagów, którzy usiłują spełnić marzenie o wyjeździe do Ameryki i pracują nad stworzeniem długodystansowej łodzi. Ich pieczołowicie obmyślony plan zostaje brutalnie zniweczony przez zwykłą dramaturgię życia. Bohaterowie muszą zmierzyć się ze śmiercią rodziców najbardziej zapalonego wyznawcy kultury Zachodu. Motywem przewodnim opowiadania Giełasimowa jest melodia piosenki Chattanooga Choo Choo, będąca symbolem siły młodzieńczych marzeń. Autor, w przeciwieństwie do byłych uczestników ruchu, nie idealizuje młodości. Dowodzi, że przeciwności losu spotykają ludzi na każdym etapie życia, a do zderzenia marzeń z rzeczywistością może dojść nawet w trakcie ich snucia.

Portret stiliagów oscyluje wokół naiwnego mitu różowej przeszłości ${ }^{39}$. Wizerunek odbiegający od rzeczywistości wpłynął także na filmowy obraz subkultury, głównie dzięki dynamicznym dźwiękom i kolorom kojarzonym z ruchem. Na wyidealizowane postrzeganie stiliagów wpływ miały także zespoły muzyczne z lat 80 ., m.in. Brawo, Mister Twister czy Sekret. Nie tylko styl muzyki i tańca nawiązywały do brzmienia retro. Moda, fryzury i instrumenty muzyczne były celowym odwołaniem do pokolenia rodziców. Swoistą nostalgię za czasami pierwszych stiliagów można także odnaleźć w warstwie tekstowej piosenek wymienionych zespołów.

Utrwalany w przekazach kulturowych mit o stiliagach wpłynął także na społeczny wizerunek subkultury. Jednak badacze zjawiska odnoszą się do stiliagów z pewnym dystansem. Artiom Troicki określa ich jako płytkich konsumentów, odszczepieńców łaknących zabawy i radości w koszarowym środowisku ${ }^{40}$. Krytyk muzyczny dowodzi, że była to nieudana próba stworzenia subkultury młodzieżowej zapożyczonej z Zachodu. Rozpatrując termin „inscenizacja kulturowa” (proces przenikania trendów zachodnich do struktury rosyjskich subkultur $)^{41}$, należy uwzględnić fakt, że w przypadku sti-

38 Zob. m.in.: W. Aksionow, Koledzy, przeł. J. Dziarnowska, Warszawa 1961; tenże, Gwiaździsty bilet, przeł. I. Piotrowska, Warszawa 1962.

39 Zob.: J. Szacki, Spotkania z utopia, Warszawa 1980.

40 А. Троицкй, Рок в Союзе..., s. 15.

41 А. Ионин, Социология культуры..., s. 176. 
liagów była to inscenizacja nieudolna, stanowiąca karykaturalny obraz Amerykanów $\mathrm{i}$ ich kultury.

$\mathrm{Z}$ drugiej strony, nie odwołując się do treści mitycznych, należy zwrócić uwagę na fakty świadczące o fenomenie ruchu stiliagów. Po pierwsze, subkultura była pierwszym nonkonformistycznym ruchem młodzieży, mającym wpływ na postrzeganie adolescencji i tworzącą się kulturę młodzieżową. Po drugie, preferowane przez stiliagów muzyka i taniec stanowiły zalążek rodzącej się w ZSRR kultury rock'n'rolla. Na koniec warto wspomnieć o slangu członków subkultury, który wyszedł daleko poza ramy ruchu, oraz tradycyjnych miejscach spotkań stiliagów, stanowiących również punkt zbiórek dla kolejnych subkultur w Rosji.

Nie ma wątpliwości, że trudno badać odległy fenomen kulturowy, pomijany w opisach naukowych przez dziesiątki lat. Zgromadzona literatura jest tworzona na podstawie relacji świadków i uczestników ruchu, sporządzanych z pewnego dystansu czasowego. Tego typu wspomnieniom towarzyszy, co zrozumiałe, nostalgia za minionymi latami młodości. Trudno zatem oddzielić warstwę mityczną, utrwaloną w przekazach literackich i filmowych, od odległej rzeczywistości.

\section{BIBLIOGRAFIA}

\section{Źródła}

Аксенов В., В поисках грустного беби, Москва 2000.

Козмов А., Козён на саксе, [online] http://www.musiclab.ru.

Славкин В., Памятник неизвестному стимяге, Москва 1996.

\section{Opracowania}

Багдасарян О., Взрослая дочь молодого человека и Памятник неизвестному стиляге B. Славкина: поколение 1950-х в эпоху застоя, „Политическая мингвистика” 2010, nr 3. Bąk T., Wspótczesne uwarunkowania kreacji subkultur mtodzieżowych, Warszawa 2008. Chłopek M., Bikiniarze. Pierwsza polska subkultura, Warszawa 2005.

Аарк О., Крушение космоса, „Неприкосновенный запас” 1999, nr 2, [online] http://magazines.russ.ru/nz/1999/2/dark-pr.html.

Duda K., Między realizmem a postmodernizmem. Generation P Wiktora Pielewina, „Slavia Orientalis" 2004, nr 2.

Dudek A., Między groteska a rzeczywistościq wirtualna. Wiktor Pielewin Generation P, [w:] Humanistyka slawistyczna dziś. Nowe spojrzenie i stanowiska, red. L. Suchanek, Kraków 2005, Prace Komisji Kultury Stowian PAU, 4.

Historia literatury rosyjskiej XX wieku, red. A. Drawicz, Warszawa 2002.

Ионин $\Lambda$., Социология культуры: путь в новое тысячеметие, Москва 2000.

Jawłowska A., Drogi kontrkultury, Warszawa 1975, Biblioteka Myśli Wspótczesnej.

Matyukhina A., W sowieckim Lwowie. Życie codzienne miasta w latach 1944-1990, Kraków 2000.

Piotrowski P., Subkultury mtodzieżowe. Aspekty psychospoteczne, Warszawa 2003. 
„Przegląd Rusycystyczny” 2011, R. 33, nr 2: Odwilż i pokolenie lat sześćdziesiątych.

Рот-Ай К., Кто на пьедестале, а кто в толпе? Стиляги и идея советской „молодежной культуры” в эпоху „оттепеми”, „Неприкосновенный запас” 2004, nr 4, [online] http:// magazines.russ.ru/nz/2004/4/ra4-pr.html.

Szacki J., Spotkania z utopia, Warszawa 1980.

Tarnavskyi V., Dzieci swoich czasów. Ruchy mtodzieżowe w Rosji a zmiany kulturowe po upadku ZSRR, Warszawa 2007.

Троицкй А., Рок в Союзе: 60-е, 70-е, 80-е, Москва 1991.

Вайль П., Генис А., 60-е. Мир советского человека, Ann Arbor 1988.

Dr Martyna KOWALSKA - doktor nauk humanistycznych w zakresie literaturoznawstwa, kulturoznawca, rosjoznawca. Adiunkt w Instytucie Rosji i Europy Wschodniej UJ, członek Komisji Kultury Słowian PAU. Zajmuje się rosyjską kulturą i literaturą XX w., zjawiskiem dysydentyzmu i inakomyslija, problemem emancypacji kobiet w ZSRR, a także kulturowymi ruchami młodzieżowym w Rosji. Autorka monografii Aleksander Sotżenicyn. Homo sovieticus i cztowiek sprawiedliwy (Torun 2011) i kilkunastu artykułów naukowych o tematyce rosjoznawczej. 